Proc. Indian Acad. Sci. (Earth Planet. Sci.), Vol. 103, No. 1, March 1994, pp. 17-26.

(C) Printed in India.

\title{
A two-stage evolution of Visakhapatnam-Paradip shelf, east coast of India, from magnetic studies
}

\author{
A S SUBRAHMANYAM, K S R MURTHY, T C S RAO, \\ $M$ M MALLESWARA RAO, S LAKSHMINARAYANA and \\ $K$ VENKATESWARLU \\ National Institute of Oceanography, Regional Centre, 176, Lawsons Bay Colony, \\ Visakhapatnam 530017 \\ MS received 23 August 1993; revised 28 February 1994
}

\begin{abstract}
A detailed analysis of bathymetry and magnetic data of Visakhapatnam-Paradip shelf, east coast of India revealed three major structural lineaments over the shelf/slope of the area. Models derived from the anomalies associated with the trends indicate that trend A represents horst and graben type continental basement while trend $B$ is due to a series of dyke intrusions. Trend $C$ off Chilka lake forms the northward extension of $85^{\circ} \mathrm{E}$ lineation from deep sea Bengal Fan.

A two stage evolution of the eastern continental margin of India has been inferred from the study of this part of the margin, viz., the rift stage evidenced by dyke intrusions of reverse polarity located within the inner part of the shelf and post-rift stage characterized by vertical tectonics in the form of a horst and graben type continental basement. The hotspot related aseismic $85^{\circ} \mathrm{E}$ ridge further complicated the tectonics of this part of the area.
\end{abstract}

Keywords. Magnetic basement; dyke intrusions; $85^{\circ} \mathrm{E}$ lineation.

\section{Introduction}

The eastern passive continental margin of India (ECMI) was formed by the separation of Indian plate from combined Australia and Antarctica Plate. Its subsequent northward drift resulted in the formation of the Bay of Bengal and the largest sediment fan in the northern part, known as the Bengal Fan (Curray and Moore 1974). Accordingly, the ECMI also might have undergone the four stages of evolutionary history of passive margins viz., 1) An initial rift; 2) Opposed drift of the continental blocks; 3) Creation of oceanic crust; and 4) Deposition and accumulation of sediments on the newly formed oceanic crust (Heezen 1974). In recent years several aspects of stratigraphy, structure and sedimentation of the eastern continental margin of India from Visakhapatnam to Paradip have been reported by different workers (Banerjee et al 1988; Murthy 1989; Mukhopadhyay and Krishna 1991). In this paper magnetic and bathymetric data from Visakhapatnam to Paradip are analysed and possible evolutionary stages of ECMI are discussed.

\subsection{Geology of the area}

The study area lies seaward of Andhra-Orissa coast and the coastal geology mainly comprises of Precambrian rocks with predominant NE-SW trend (figure 1). It is divided into two major blocks based on coastal geology. 


\subsection{Visakhapatnam-Gopalpur block}

This area is flanked by eastern ghats, largely comprised of khondalites and charnockites associated with metamorphosed manganiferrous sediments. These rocks have undergone high grade metamorphism at greater depths and were later subjected to block upliftment (Krishnan 1982).

\subsection{Gopalpur-Paradip block}

This region forms the southern part of offshore Mahanadi basin, a pull apart type of basin formed by the break up of Gondwanaland during upper Palaeozoic to upper Jurassic period. Onshore basin is largely covered by Holocene deposits. The basement is composed of Archaean metamorphic complex covered by Precambrian metasediments, amphibolites and schists intruded by granite gneisses (Mishra et al 1984).

\subsection{Offshore geology and stratigraphic sequence}

Tectonically, offshore Mahanadi basin falls into four distinct zones viz., 1) Linear ridges and depressions; 2) Southerly dipping basement characterized by faults; 3) A hinge over Eocene shelf margin; and 4) A zone of growth faults and structures. The shelf is characterized by metamorphic basement overlain by Cretaceous volcanics of

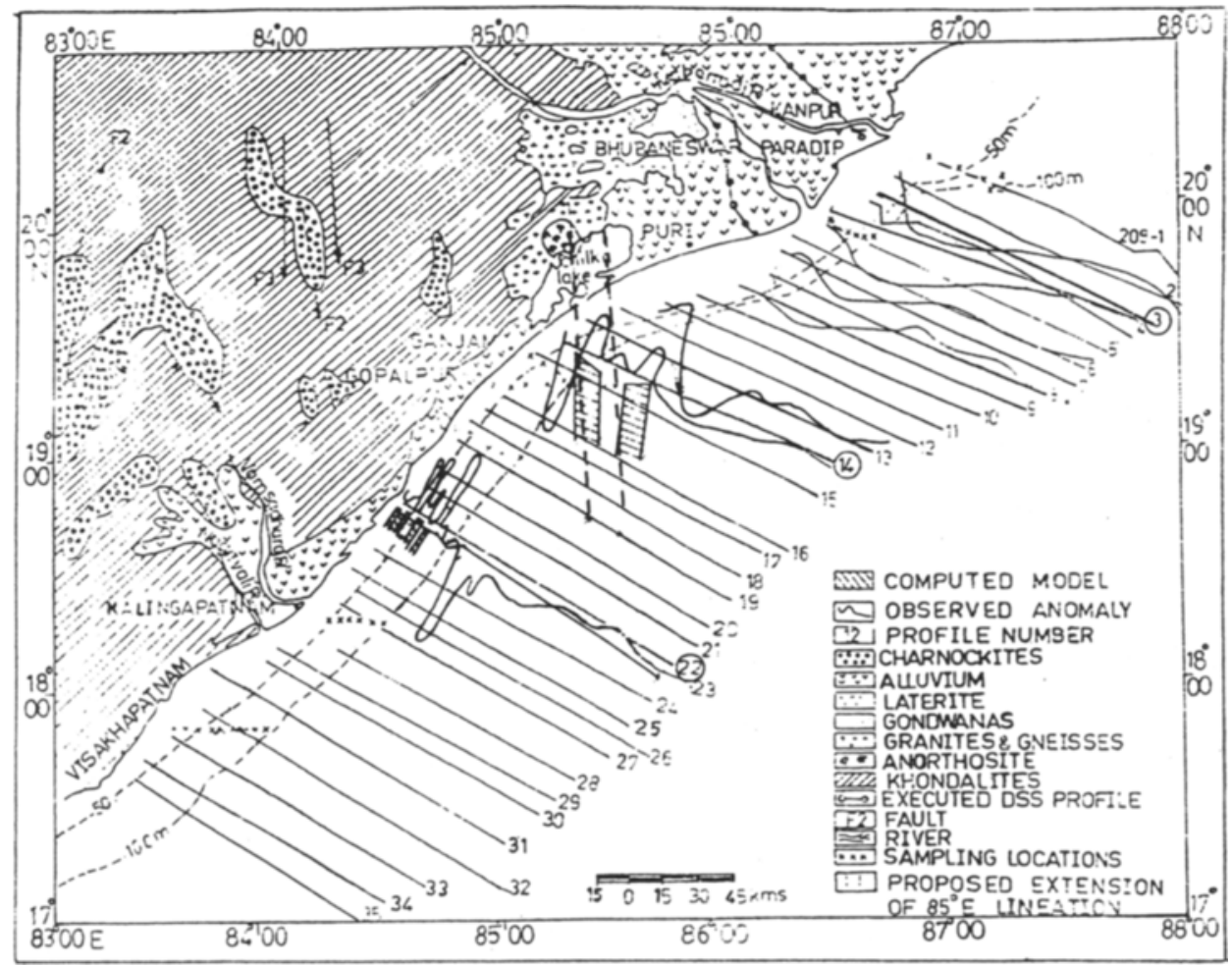

Figure 1. Location map of the study area showing coastal geology, tracks covered, interpreted models along with corresponding anomalies. 
varying thickness which in turn are unconformably overlain by Tertiary sediments, both clastics and carbonates of predominantly shallow marine origin with thickness varying from $2000 \mathrm{~m}$ near coast to $4000 \mathrm{~m}$ near the shelf edge (Jagannatham et al 1983 ).

\section{Data acquisition}

Marine geophysical surveys comprising of magnetic and bathymetric data were carried out over the continental shelf between Visakhapatnam in the southwest and Paradip in the northeast $\left(17^{\circ} \mathrm{N}\right.$ to $20^{\circ} \mathrm{N}$ and $83^{\circ} \mathrm{E}$ to $\left.88^{\circ} \mathrm{E}\right)$. Totally 34 traverses each of about $140 \mathrm{~km}$ in length taken perpendicular to the coast (NW-SE) at a spacing of about $10 \mathrm{~km}$ have been used in the present study. Location of profiles is shown in figure 1. All profiles are confined to continental shelf-slope margin region from about $30 \mathrm{~m}$ to about $3000 \mathrm{~m}$ water depth. Magnetic and bathymetric data were acquired during cruises of Regional Centre of NIO, Visakhapatnam on board the Research Vessel R. V. Gaveshani during 1989. The positions of the tracks were obtained by satellite navigation (NAVSAT) system with an accuracy of $\pm 20 \mathrm{~m}$ (Eaton et al 1976). Bathymetry data were collected using a narrow beam echosounder (frequency $30 \mathrm{khz}$ ). Bathymetry contour map with an interval of $50 \mathrm{~m}$ is shown in figure 2. Magnetic data were collected using Barringer proton precession magnetometer at one minute interval corresponding to a distance of about $230 \mathrm{~m}$ at ship's speed of $8 \mathrm{knots} / \mathrm{hr}$. Magnetic data has been corrected for IGRF 1985 (Barraclough 1988). Isonanoteslamap of the study area compiled at variable contour interval of $20 \mathrm{nT}$ and $100 \mathrm{nT}$ is shown in figure 3.

\section{Results and discussion}

Bathymetry map (figure 2) indicates that the shelf width is narrow $(50 \mathrm{~km})$ between Visakhapatnam and Chilka lake compared to north between Chilka lake and Paradip

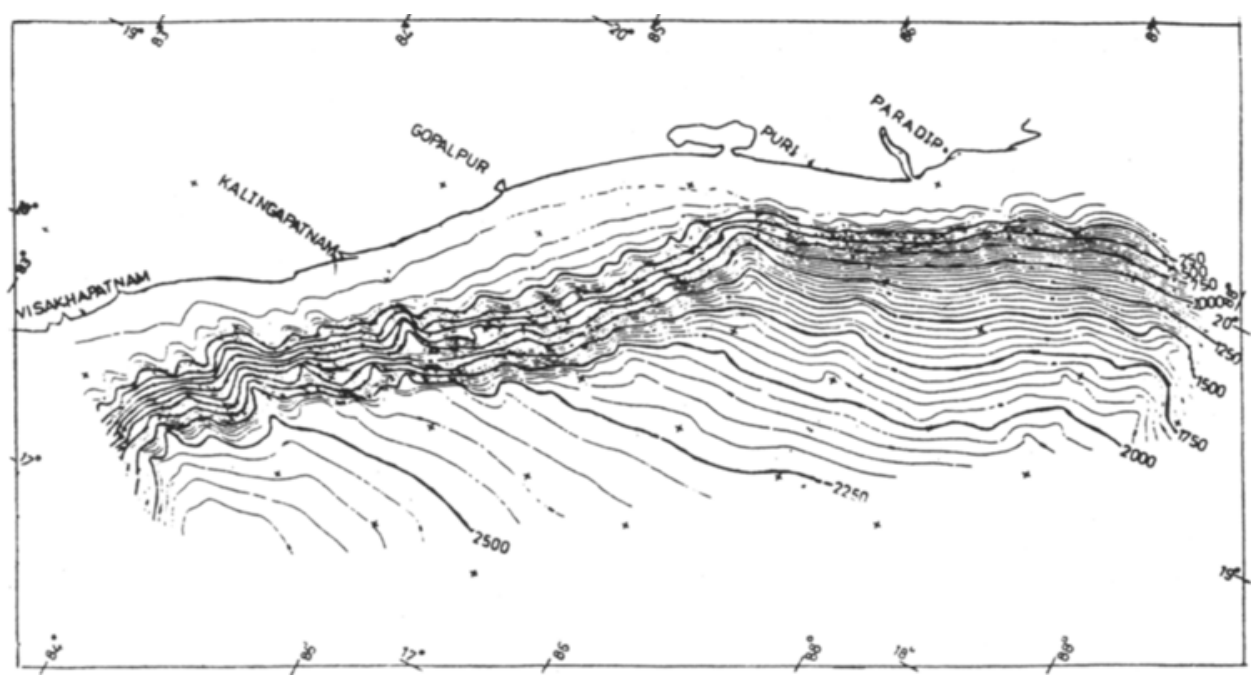

Figure 2. Bathymetry contour map of the study area (interval $50 \mathrm{~m}$ ) showing narrow shelf between Visakhapatnam and Gopalpur and a wider one between Gopalpur and Paradip. 


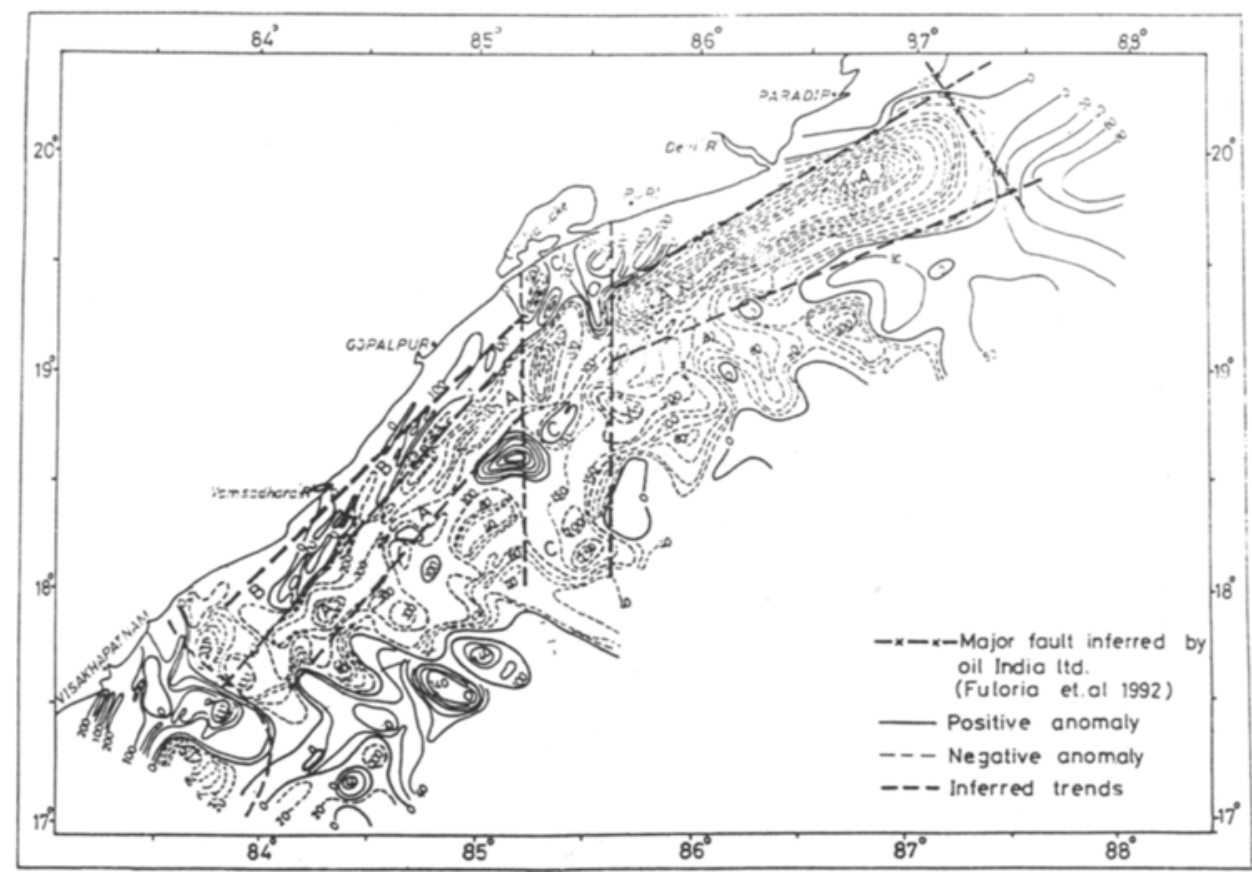

Figure 3. Total field magnetic anomaly contour map of the study area (interval $20 \mathrm{nT}$ and $100 \mathrm{nT}$ ) showing trends A, B and C caused by horst and graben type basement configuration, basic intrusives and probable northward extension of $85^{\circ} \mathrm{E}$ lineation respectively.

$(70 \mathrm{~km})$. The shelf gradient varies from 1:200 to 1:300 between Visakhapatnam and Paradip. The outer shelf off Visakhapatnam is associated with reefs and terraces forming as lineations running parallel to the coast (Murthy 1989). The characteristics of echograms suggest that the outershelf between Visakhapatnam and Gopalpur is rugged and to the north of Gopalpur upto Paradip the echograms indicate smooth topography comprising of recent sediments (Rao et al 1988).

\subsection{Analysis of magnetic data}

Total intensity magnetic anomaly map (figure 3 ) is characterized by three distinct magnetic anomaly patterns: 1) A prominent broad negative anomaly belt trending NE-SW parallel to the coast with amplitudes of $-300 \mathrm{nT}$ to $-500 \mathrm{nT}$ from Paradip to north of Visakhapatnam (marked $A$ in figure 3 ) with a strike length of about $450 \mathrm{~km}$ suggesting a major tectonic feature. This is flanked seaward by positive anomaly closures of about $80 \mathrm{nT}$ off Paradip and $120 \mathrm{nT}$ off Visakhapatnam; 2) A linear short wavelength but relatively low amplitude anomaly trend between Gopalpur and Visakhapatnam (marked B) recorded landward of the NE-SW trend A. These anomalies are conspicuously absent over the northern part between Gopalpur and Paradip (figure 4), probably masked by thick deltaic sediments (of about $2000 \mathrm{mts}$ near shore) from Mahanadi river. The anomalies recorded east of Chilka lake and Puri are gentle gradient and long wave length unlike the anomalies represented by trend B; 3) A prominent high amplitude asymmetric magnetic anomaly lineation of 


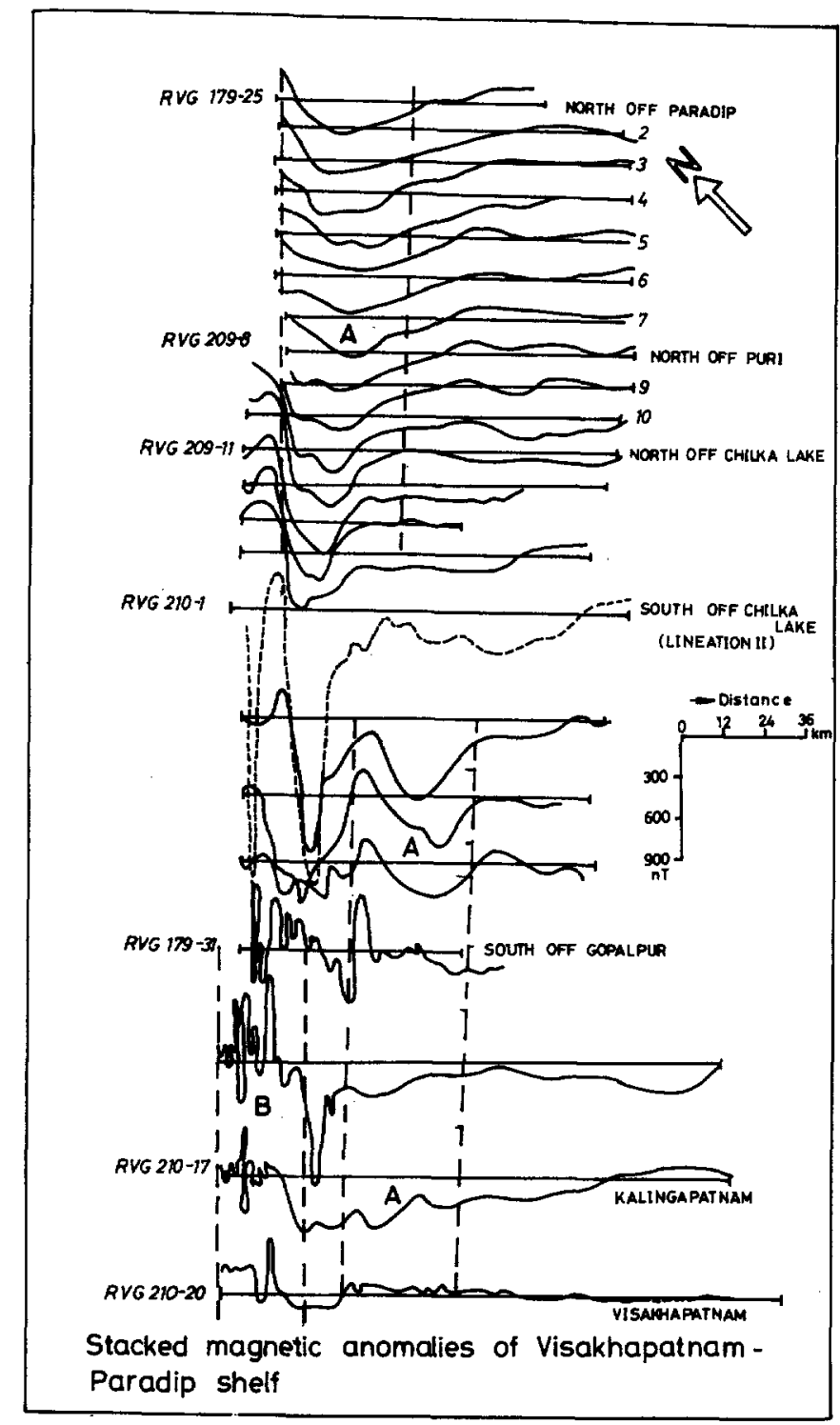

Figure 4. Stacked magnetic anomaly sections of Visakhapatnam to Paradip shelf showing trends $\mathrm{A}, \mathrm{B}$ and $\mathrm{C}$.

small areal extension, with amplitude of the order of $1800 \mathrm{nT}$ over the inner shelf south of Chilka lake, trending approximately $\mathrm{N}-\mathrm{S}$ (marked as $\mathrm{C}$ in figure 3 ). There is a significant change in the width of the anomaly at the trend $C$. The width increases towards north east which may probably indicate the beginning of Mahanadi Offshore basin marked by wider and deeper basement structure. This trend intersects the major NE-SW trend A off Chilka lake. Babu Rao et al (1982) from aeromagnetic studies reported anomalies of similar nature over the offshore regions of Chilka lake.

A minor $\mathrm{E}-\mathrm{W}$ trending negative anomaly with an amplitude of about $-100 \mathrm{nT}$ to $-200 \mathrm{nT}$ is observed north of Visakhapatnam (figure 3 ) which appears to intersect 
$\mathrm{NE}-\mathrm{SW}$ trend $\mathrm{A}$. This $\mathrm{E}-\mathrm{W}$ trend correlates well with the major fold axis swerving into offshore region north of Visakhapatnam reported earlier by Sriramdas and Rao (1979) and Murthy et al (1987b).

Magnetic data along three representative sections viz., south of Paradip, off Chilka lake and south of Gopalpur (figure 4) characterized by anomalies of the three major trends described earlier are analysed to delineate the magnetic basement structure of the study area. The anomalies are interpreted using the method of Talwani and Heirtzler (1964). The observed and computed magnetic anomalies and the resulting basement structure are shown in figures $5 \mathrm{a}, 5 \mathrm{~b}$ and $5 \mathrm{c}$.

Models derived from the magnetic anomaly associated with trend $A$ suggest an undulating basement resembling a horst and graben configuration (figure 5a). The maximum depth obtained to the base of the graben, off Paradip is of the order of $6 \mathrm{~km}$, whereas the flanks on either side varied from $1.5 \mathrm{~km}$ (landward) to $3 \mathrm{~km}$ (seaward). The horst and graben basement model correlate well with the results obtained from Deep Seismic Sounding (DSS) on adjacent onshore Mahanadi Basin by Kaila et al (1987) in the absence of magnetic data between $30 \mathrm{~m}$ water depth and the coast line. While the DSS results report the horst and graben configuration beneath the onshore Mahanadi Basin, the present study suggests its extension both offshore and further south west up to Visakhapatnam as reflected by the trend $A$ in figure 3.

Model studies from the analysis of magnetic anomalies of trend $B$ indicate that the normally magnetised continental crust is intruded by a series of shallow, highly magnetic and juxtaposed intrusive bodies of different magnetisation contrasts at depths varying from $600 \mathrm{~m}$ to $3000 \mathrm{~m}$ (figure $5 \mathrm{~b}$ ). Earlier studies by Murthy et al (1993) also indicate the presence of such intrusives within the continental crust off Madras, which are interpreted as due to rift related volcanism. Similar occurrences of rift related intrusives are reported over south western continental margin of Australia (Veevers et al 1985). The derived model and the remanent magnetisation parameters from the present study also indicate that these intrusive bodies might have originated during the initial stages of rifting of the ECMI. These are different
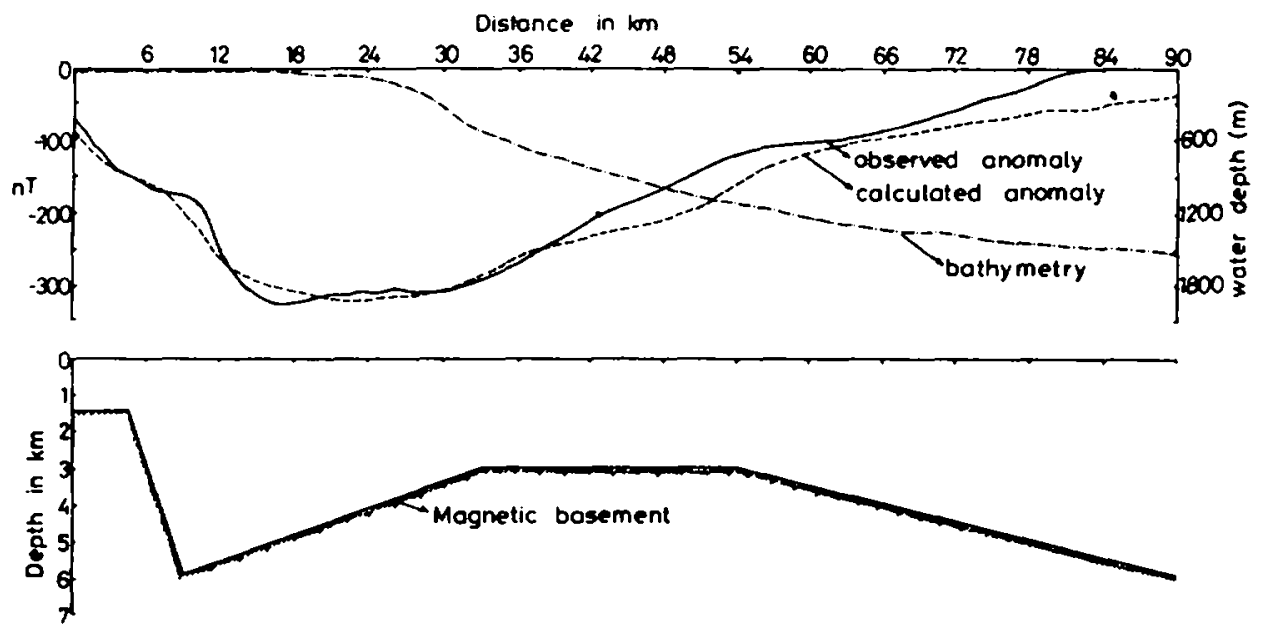

Fingre 5a. Two dimensional modelling inferred from magnetic anomaly of Paradip showing horst and graben basement structure. 


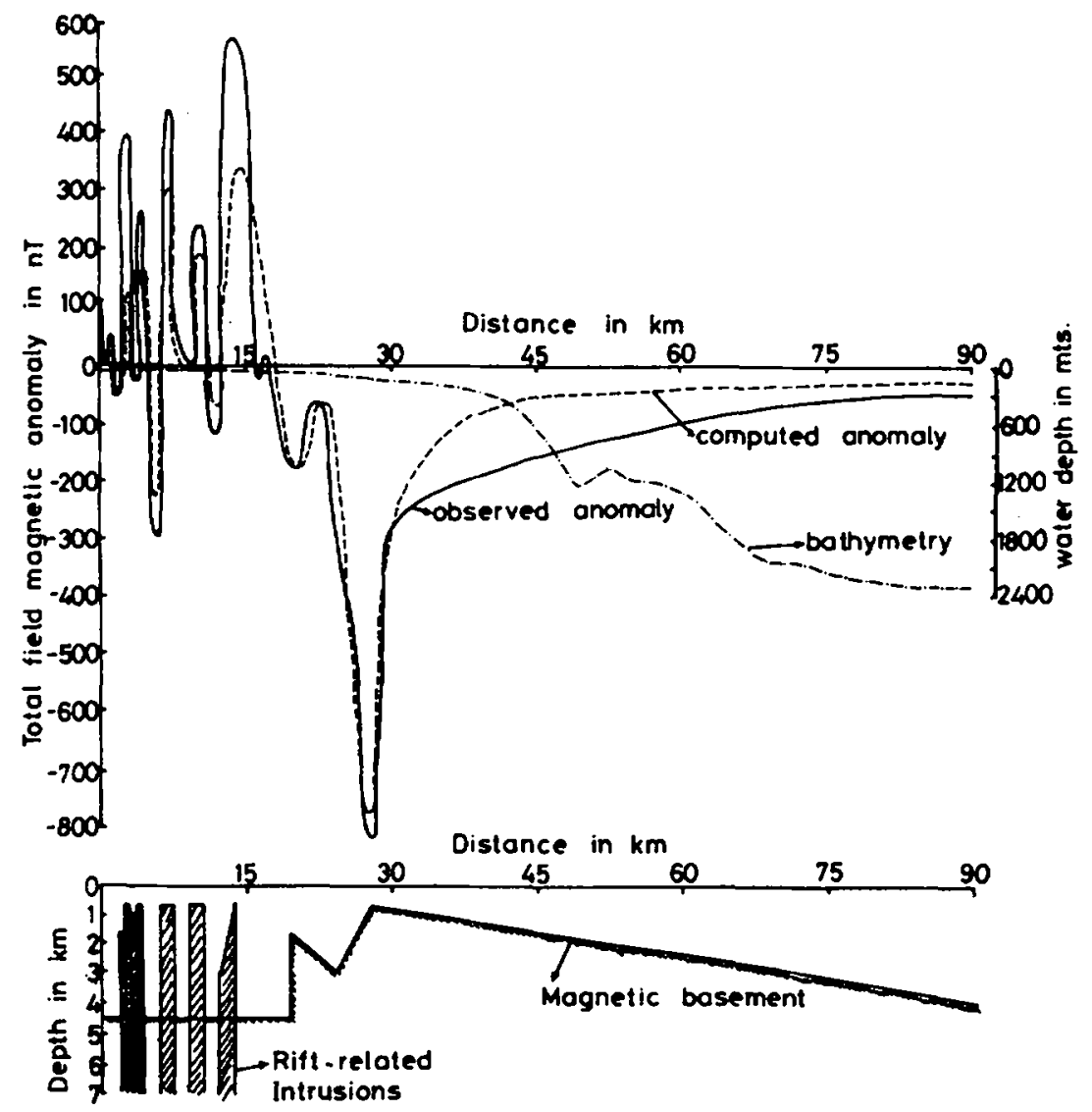

Fizure st. Two dimensional modelling of magnetic anomaly off Gopalpur showing rift related intrusive bodies impregnated into horst and graben basement structure.

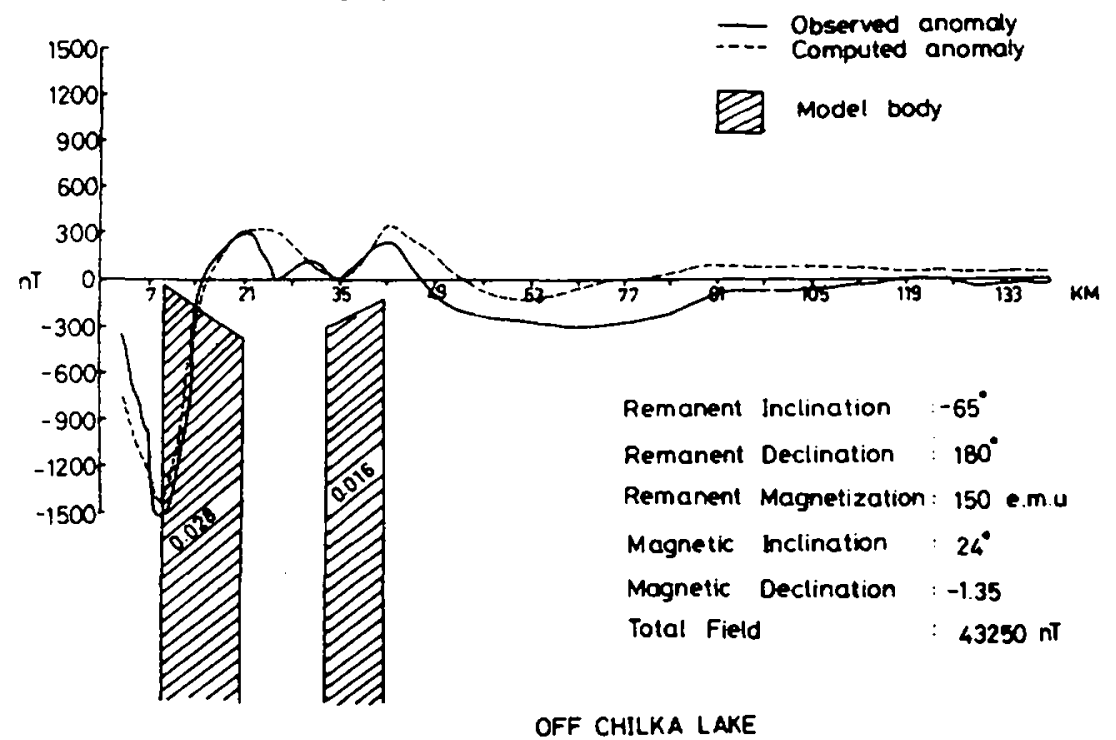

Figure Sc. Two dimensional modelling of magnetic anomaly off Chilka lake showing the two intrusive models indicating the inferred northward extension of $85^{\circ} \mathrm{E}$ lineation. 
from the charnockitic intrusions reported on some parts of the east coast of India cutting across the coast in NW-SE, as the present lineation runs parallel to the coast (trend B).

Magnetic models constructed on the basis of two dimensional source bodies from the $\mathbf{N}-\mathbf{S}$ trending asymmetric anomaly (trend $\mathrm{C}$ ) recorded south of Chilka lake indicate two shallow mafic intrusives at depths of 0.6 to $3.6 \mathrm{~km}$ (landward) and 0.6 to $4.5 \mathrm{kms}$ (seaward) separated laterally by a distance of about $10 \mathrm{~km}$ (figure $5 \mathrm{c}$ ). Best possible fit between observed and computed models is obtained assuming high susceptibility constrasts of 0.028 and $0.016 \mathrm{emu}$ for landward and seaward intrusives respectively and by assuming remanent magnetization parameters (remanent inclination $=-65^{\circ}$ and declination $\left.=180^{\circ}\right)$. Palaeolatitude $\left(47^{\circ} \mathrm{S}\right)$ computed from the palaeomagnetic parameters used in the modelling of the anomaly indicates that these intrusives might have erupted within the Indian plate when the latter was located in the southern hemisphere. This $\mathrm{N}-\mathrm{S}$ lineation is also recorded upto $12^{\circ} \mathrm{N}$ in the southern Bay of Bengal from long range profiles (Murthy et al 1993) though with reduced amplitude and it represents the extension of the buried $85^{\circ} \mathrm{E}$ ridge in the Bengal Fan reported for the first time by Curray et al (1982). If this trend is extended further on to the Indian subcontinent, it connects to the Rajmahal traps (of upper Jurassic age) indicating probable common source of origin for both these features. Curray and Munasinghe (1991) attributed to hotspot origin for the $85^{\circ} \mathrm{E}$ ridge as well as Rajmahal traps. It is therefore likely that the two intrusives might represent the trace of the hotspot over which the Indian plate migrated in a northward trend. The high natural remanent magnetisation and high susceptibility obtained for the $85^{\circ} \mathrm{E}$ ridge anomaly suggests that the formation is composed of highly magnetised rock like serpentinite (altered product of peridotite) generally emplaced in the form of vertical tectonic protrusions (Bonatti 1976). Occurrence of peridotites onland at Chilka lake (Babu Rao personal communication) also supports northward continuation of this feature upto $20^{\circ} \mathrm{N}$. The asymmetric magnetic anomaly pattern recorded above $85^{\circ} \mathrm{E}$ ridge may be due to phase shift produced by the northward drift of the Indian plate as reported earlier (McKenzie and Sclater 1971; Schouten 1971). The two intrusive configuration deduced from the present study closely agrees with the occurrence of very prominent double humped feature corresponding to the $85^{\circ} \mathrm{E}$ ridge from the multichannel reflection data at $13^{\circ} \mathrm{N}$ (Gopal Rao et al 1991). Thus the present analysis shows the lineation of $85^{\circ} \mathrm{E}$ ridge and its possible extension, (figure 1) abutting the continental shelf of Chilka lake. However, it is not possible from the present model studies to distinguish the magnetisation properties between rift related dykes (trend $B$, between Gopalpur and Visakhapatnam) and those associated with hotspot activity of $85^{\circ} \mathrm{E}$ ridge (trend $\mathrm{C}$, south off Chilka lake). The trend $C$ approximately parallels a major fault zone identified by Fuloria et al (1992) at about $87^{\circ} \mathrm{E}$ longitude. According to them this fault marks the NE limit of the Mahanadi offshore basin whereas the trend $\mathrm{C}$ from the present study may be considered as the SW limit of the Mahanadi offshore basin.

\section{Conclusions}

In summary, the present study based on magnetic data (figure 1) gives evidence for at least two stages of evolution of the eastern continental margin of India: 1) Rift 
phase represented by the two intrusive bodies (trend B); 2) Post rift stage represented by horst and graben configuration (trend $\mathrm{A}$ ) over the shelf region. The study also suggests possible extension of $85^{\circ} \mathrm{E}$ ridge (trend $\mathrm{C}$ ) into the land area adjacent to the eastern continental margin of India.

\section{Acknowledgements}

The authors are grateful to $\operatorname{Dr} B$ N Desai, Director, National Institute of Oceanography, Dona Paula, Goa for his constant encouragement; and their colleagues who helped in acquisition of the data.

\section{References}

Babu Rao V, Atchuta Rao D, Sanker Narayan P V and Ratnam C 1982 Aeromagnetic survey over parts of Mahanadi Basin and the adjoining offshore region, Orissa, India; Geophys. Res. Bull. 20 219-220

Banerjee P K, Bose P K and Ghosh N 1988 Geophysical survey and exploration for mineral deposits of sea-bed around India; J. Assoc. Explor. Geophys. 9 141-151

Barraclough D R 1988 International Geomagnetic Reference Fjeld 1987; J. Geophys. 93 187-189

Bonatti Emrico 1976 Serpentinite protrusions in the oceanic crust; Earth Planet. Sci. Lett. 32 107-113

Curray Joseph R and Moore D G 1974 Sedimentary and tectonic processes in the Bay of Bengal Deep Sea Fan and Geosyncline 617-627; In The Geology of Continental Margins (eds) C A Burk and C L Drake (New York: Springer-Verlag) $1009 \mathrm{pp}$

Curray Joseph R, Emmel F J, Moore D G and Raitt R W 1982 Structure, tectonics and geological history of the northeastern Indian Ocean; In: Ocean basins and margins 6 The Indian Ocean (eds) A E M Nairn and F G Stehli (New York: Plenum) pp. 399-450

Curray J R and Tissa Munasinghe 1991 Origin of the Rajmahal traps and the 85E Ridge: Preliminary reconstructions of the trace of the Crozet hotspot; Geology 19 1237-1240

Eaton R M, Wells D E and Stuitbergen N 1976 Satellite navigation in hydrography; In International Hydrographic Review LIII (1) 99-110

Fuloria R C, Pandey R N, Bharali B R and Mishra J K 1992 Stratigraphy, structure and tectonics of Mahanadi offshore Basin; Geol. Sur. India Spl. Publ. 29 255-265

Gopal Rao D et al 1991 A multi-channel seismic reflection and magnetic study (along $13^{\circ}$ north parallel) across the Bay of Bengal; Souvenir A E G A48-A49

Heezen B C 1974 Atlantic type continental margins 13-24; In The geology of Continental margins (eds) C A Burk and C L Drake Inc. (New York: Springer Verlag) 1009 pp

Jagannatham C R, Ratnam C, Baishya, N C and Das Gupta V 1983 Geology of offshore Mahanadi Basin; Pet. Asia J. 101-104

Kaila K H, Tewari H C and Mall D M 1987 Crustal structure and delineation of Gondwana Basin in the Mahanadi delta area, India, from deep seismic sounding, J. Geol. Soc. India 29 293-308

Krishnan M S 1982 Geology of India and Burma text book 4th edition (Madras: Higginbothams) pp. 604

McKenzie D and Sclater J G 1971 The evolution of the Indian Ocean since late Cretaceous; Geophys. J. R. Astron. Soc. 25 437-528

Mishra D C, Venkatarayudu M and Laxman G 1984 Three dimensional model of Mahanadi Basin from potential field data; Petrol. Asia J. 167-174

Mukhopadhyay M and Krishna M R 1991 Gravity field and deep structure of the Bengal Fan and its surrounding continental margins, north east Indian ocean; Tectonophysics 186 365-386

Murthy K S R, Rao T C S and Rao M M M $1987 \mathrm{~b}$ Delineation of structural lineaments from marine magnetic anomalies off Lawson's Bay (Visakhapatnam) east coast of India; Indian J. Mar. Sci. 16 19-21

Murthy K S R 1989 Seismic stratigraphy of Ongole-Paradip continental shelf east coast of India; Indian J. Earth Sci. 16 47-58

Murthy K S R, Rao T C S, Subrahmanyam A S, Malleswara Rao M M and Lakshminarayana S 1993 Structural lineaments from the magnetic anomaly maps of the Eastern Continental Margin of India (ECMI) and NW Bengal Fan Marine Geology 114 171-183 
Rao T C S, Murthy K S R, Subrahmanyam A S, Mohana Rao K, Reddy N P C and Lakshminarayana S 1988 Geophysical and geological investigations over continental margins of east coast of India; $T e c h$. Report No. NIO/TR-3/88.

Schouten J A 1971 A fundamental analysis of magnetic anomalies over oceanic ridges; Mar. Geophys. Res. 1 111-144

Sriramadas A and Rao A T 1979 Charnockites of Visakhapatnam; Andhra Pradesh J. Geol. Soc. India $20512-517$

Talwani $M$ and Heirtzler J R 1964 Computation of magnetic anomalies caused by a two dimensional structure of arbitrary shape; In Computers in the mineral industries (ods) G A Parks (Stanford University) 464-480

Veevers J J, Tayton J W, Johnson B D and Hansen L 1985 Magnetic expression of continental ocean boundary between western margin of Australia and eastern Indian Ocean; J. Geophys. 56 106-120 